\title{
Size-selective predation of 0 -group flatfishes on a Scottish coastal nursery ground
}

\author{
$\operatorname{Tim}_{\text {Ellis }}{ }^{1,2, *}$, Robin N. Gibson ${ }^{1}$ \\ ${ }^{1}$ Dunstafinage Marine Laboratory, PO Box 3, Oban, Argyll PA34 4AD, United Kingdom \\ ${ }^{2}$ Port Erin Marine Laboratory, University of Liverpool, Port Erin, Isle of Man IM9 6JA, United Kingdom
}

\begin{abstract}
Fish predation on 0-group flatfish (plaice Pleuronectes platessa, dab Limanda limanda and flounder Pleuronectes flesus) populations on Tralee Beach, Scotland (56 $31^{\prime} \mathrm{N}, 5^{\circ} 29^{\prime} \mathrm{W}$ ) was studied by stomach content analysis during the summers of 1992 and 1993. I-group grey gurnard Eutrigla gurnardus, poor-cod Trisopterus minutus and whiting Merlangius merlangus and 0-group cod Gadus morhua were the major fish predators of the 0 -group flatfishes. Flatfishes $>45 \mathrm{~mm}$ total length appeared to have a refuge in size from predation by the fishes sampled. Predation by fishes was shown to be negatively size-selective, concentrated on the smaller size-classes of flatfishes. Smaller individuals were eaten by a greater taxonomic variety and a larger size range of predators than larger flatfishes. Smaller flatfishes were therefore vulnerable to a larger number of predators. The size distributions of predators affected the pattern of predation because only the larger individuals ate flatfishes. It is therefore proposed that the degree of overlap in the size distributions of predators and prey determine the magnitude of predation. Growth rates and the timing of settlement in any one year will therefore have a considerable influence on predation, with the potential to result in a 'match or mismatch' of predator and prey size distributions.
\end{abstract}

KEY WORDS: Predation - Nursery ground - Size distributions - Match-mismatch · Pleuronectes platessa Limanda limanda. Pleuronectes flesus - Gadus morhua

\section{INTRODUCTION}

The larval stages of plaice Pleuronectes platessa, dab Limanda limanda, and flounder Pleuronectes flesus are planktonic (Russell 1976). After metamorphosis, the settled juvenile stages inhabit shallow inshore nursery grounds with a sandy substratum (e.g. Macer 1967, Edwards \& Steele 1968, van der Veer et al. 1991). Following the transition from the 3-dimensional pelagic environment to the 2 -dimensional benthic environment (Chambers \& Leggett 1992), the juvenile stages are concentrated at high density in these spatially limited nursery areas (Bergman et al. 1988).

The accessibility and ease of sampling of soft substratum inshore nursery grounds has prompted many studies of the mortality rates of 0 -group flatfish populations (see Iles \& Beverton 1991 for recent synthesis).

\footnotetext{
- Present address: M.A.F.F. Directorate of Fisheries Research, Fisheries Laboratory, Benarth Road, Conwy, Gwynedd LL32 8UB, United Kingdom.E-mail: t.ellis@dfr.maff.gov.uk
}

Mortality rates on nursery grounds are high, 30 to $70 \%$ per month is typical of British nurseries (Bannister et al. 1974). Predation is hypothesised to be the major cause of mortality of 0-group flatfishes on nursery grounds (Macer 1967, Steele \& Edwards 1970, van der Veer et al. 1990, Beverton \& Iles 1992a). Furthermore, it has been suggested that mortality is density-dependent during the juvenile stage on nurseries (Lockwood 1980, van der Veer 1986, Beverton \& Iles 1992b). Predation, as the major cause of mortality, must therefore be implicated in density-dependent mortality (see Lockwood 1980, van der Veer \& Bergman 1987).

High densities of small fishes suffering high mortality rates in accessible, readily sampled inshore areas provide conditions tractable for field studies of predation on fishes. The seminal study of van der Veer \& Bergman (1987) examined predation by brown shrimp Crangon crangon on plaice on the Wadden Sea nursery ground. Their quantification of mortality from shrimp predation approximated total mortality, thereby substantiating the hypothesis of the impor- 
tance of predation. Van der Veer \& Bergman (1987) also demonstrated the importance of predator size and prey size in predator-prey relationships (see also Gibson et al. 1995). Moreover, van der Veer \& Bergman (1987) went on to hypothesise that intra-annual and inter-annual variation in the numbers of shrimp predators could result in density-dependent and densityindependent mortality of 0 -group plaice populations.

The major predators of 0-group flatfishes differ among nurseries (van der Veer et al. 1990) and the high mortality rate of 0 -group plaice on open coast nurseries, for example, has been attributed to the additional presence of predatory fishes (Bergman et al. 1988). In spite of the fact that fishes are likely to exert a major influence on predation rates, the information on fish as predators of 0 -group flatfishes is fragmentary (Riley \& Corlett 1966, Macer 1967, Edwards \& Steele 1968, Lockwood 1972, Pihl 1982). Consequently, the interpretation of their effect on mortality and the determination of year-class strength is conjectural (see Lockwood 1980, van der Veer \& Bergman 1987, Bergman et al. 1988, van der Veer et al. 1990).

Edwards \& Steele (1968) found that 0-group cod Gadus morhua were an important and common predator of 0 -group plaice in Firemore Bay, a nursery ground on the west coast of Scotland. This study was initiated in 1992 on Tralee Beach, a similar Scottish nursery, to examine predation by 0 -group cod and other gadoids on 0-group flatfishes. In 1993 the study was extended to examine the nature of predation on 0 -group flatfishes by all potential fish predators.

\section{MATERIALS AND METHODS}

All samples were taken on Tralee Beach $\left(56^{\circ} 31^{\prime} \mathrm{N}\right.$ $5^{\circ} 29^{\prime} \mathrm{W}$ ), a southwest-facing open sandy beach situated at the north end of Ardmucknish Bay on the west coast of Scotland (see Gibson et al. 1993 for more detailed description and species lists). Samples were collected at night, around the time of low water (midnight), on spring tides because large numbers of gadoids are known to move into shallow water after sunset on this beach (Burrows et al. 1994). In 1992 sampling was directed towards 0-group cod and started in mid June when O-group cod recruited to the beach (pers. obs.). Six surveys of the gadoid and flatfish populations were made between mid June and September. In 1993 sampling was concentrated around the time of flatfish settlement, and 5 surveys were made of the flatfish and predatory fish populations between early May and early July.

Sampling. Potential fish predators of flatfishes were sampled close to shore ( 0 to $1.5 \mathrm{~m}$ depth) with a $36 \times$ $1.8 \mathrm{~m}$ beach seine $(8 \mathrm{~mm}$ stretched mesh in the central portion) used with $45 \mathrm{~m}$ hauling ropes (see Gibson et al. 1993). The area sampled by the beach seine was approximately $1160 \mathrm{~m}^{2}$ (Gibson et al. 1993). Two or three beach seine samples were taken on each survey. Fishes were killed with an overdose of the anaesthetic benzocaine to prevent regurgitation of stomach contents (Edwards \& Steele 1968), and preserved in approximately $4 \%$ formaldehyde in seawater. In 1992, in addition to the beach seine samples, gadoids were obtained at a depth of 4 to $5 \mathrm{~m}$ with a $3 \mathrm{~m}$ beam trawl $(8 \mathrm{~mm}$ stretched mesh in cod end) towed at approximately 1.5 knots from RV 'Seol Mara'.

The 0-group flatfish populations were sampled for length distributions with a standard Lowestoft $2 \mathrm{~m}$ beam trawl fitted with a $3 \mathrm{~mm}$ liner in the cod end (Riley et al. 1986). Trawl samples were preserved in the same manner as the beach seine samples. In 1992 the trawl was pulled parallel to the beach in $0.5 \mathrm{~m}$ depth at low tide. In 1993 population density of the flatfishes was estimated and 3 orthogonal hauls between 0 and $5 \mathrm{~m}$ depth (see Iles \& Beverton 1991) were typically taken on each survey. The average distance covered by the trawl was $150 \mathrm{~m}$, calculated from a calibrated cyclometer fitted to the shoe of the trawl.

Laboratory methods. Newly settled flatfishes from trawl samples were identified by counting fin rays (see Russell 1976). Watson (1982) was used as an identification guide to the 0-group gadoids, and other fish species were identified according to Wheeler $(1969,1992)$. The total length (TL) of the 0-group flatfishes from trawl samples was measured to the nearest $\mathrm{mm}$. Each potential predator was measured to the nearest $\mathrm{mm}$ (TL) and the contents of the stomach (including oesophagus) were examined. Fish remains recognisable as flatfish were retained. As a result of digestion it was rarely possible to use external features (e.g. lateral line, fin rays, body shape) to identify to species those flatfishes found in stomachs, and skeletal features were used instead.

To make the skeleton visible, the remains of flatfishes were partially dissolved with $2 \%$ potassium hydroxide, stained with Alizarin Red $\mathrm{S}$, and then cleared with increasing concentrations of glycerol (see Mahoney 1968). After this procedure calcified tissue was stained red and was easily discernible when viewed under a dissecting microscope. The flatfish species could then be differentiated by the number of abdominal vertebrae. In samples of fish taken from Tralee Beach, $100 \%$ of plaice $(n=54)$ had $13,96 \%$ of flounder ( $n=23$ ) had 11 , and $98 \%$ of dab ( $n=120$ ) had 10 abdominal vertebrae. These differences are typical of the 3 species (see Norman 1934, Russell 1976). Additional aids to species identification were the number of caudal vertebrae (see Norman 1934, Russell 1976) and size. 


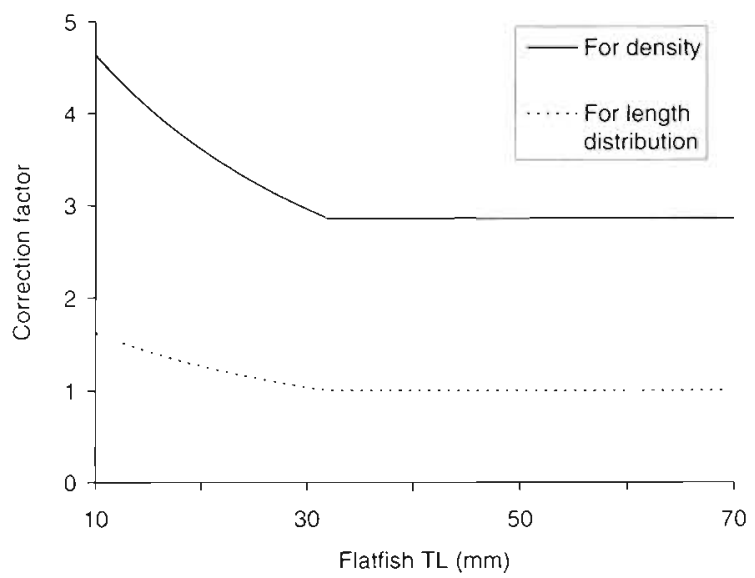

Fig. 1. Length-dependent correction factors used for adjusting flatfish (Pleuronectes platessa, Limanda limanda, Pleuronectes flesus) population density estimates and length distributions estimated from $2 \mathrm{~m}$ beam-trawl catches. Relationships derived from length-dependent gear-efficiency relationship given by Edwards \& Steele (1968)

Preserved, intact flatfishes caught from Tralee were measured and then stained and cleared in the same manner as those recovered from the stomachs of predators. The lengths of the skull and various parts of the vertebral column were measured using the eyepiece graticule of a dissecting microscope and were used to derive relationships for predicting original TL (Ellis 1994; $R^{2}$ values: 0.980 to 0.997 for regressions of log-transformed lengths). Skeletal parts of flatfishes recovered from predator stomachs were similarly measured and original size was estimated.

Flatfish population density was estimated from the area covered by the trawl (distance $\times$ beam width) after correcting for size-mediated differences in gear-efficiency (Edwards \& Steele 1968; Fig. 1). Flatfish: fish predator length ratios were arcsine transformed for statistical analysis (Zar 1984). The length distributions of eaten flatfishes were compared using Mann-Whitney $U$-tests with the length distributions of flatfishes in beam trawl samples, after correcting for size-mediated differences in trawl efficiency of flatfishes $<32 \mathrm{~mm}$ TL (Edwards \& Steele 1968, Fig. 1). Mann-Whitney $U$-tests were also used to compare the sizes of fishes that had eaten flatfishes with the length distribution of the species.

\section{RESULTS}

\section{Flatfish populations}

In 1992 the surveys started in mid June after the main settlement period of 0-group flatfishes. In 1993, 0-group plaice, dab and flounder were regularly recorded in beam trawl samples (Fig. 2A) and from predator stomachs (Table 1). Plaice settlement had already begun in early May 1993 and catches increased until mid June. Flounder were first caught later in mid May, and numbers increased until early June, after which catches decreased. No flounder were recorded after mid June. Dab were first recorded in early June, and catches increased to early July. Plaice were the most abundant flatfish on the nursery in all surveys (Fig. 2A).

Late-stage flounder larvae were recorded, but all plaice and dab had completed metamorphosis. Flounder recruited to the beach at a smaller size than plaice and dab. All plaice and dab taken in beam trawl samples were $\geq 14 \mathrm{~mm}$, whereas all flounder sampled were 10 to $13 \mathrm{~mm}$. Differences in the time and size at recruitment resulted in differences in population mean lengths, plaice being the largest and flounder the smallest (Fig. 2B).
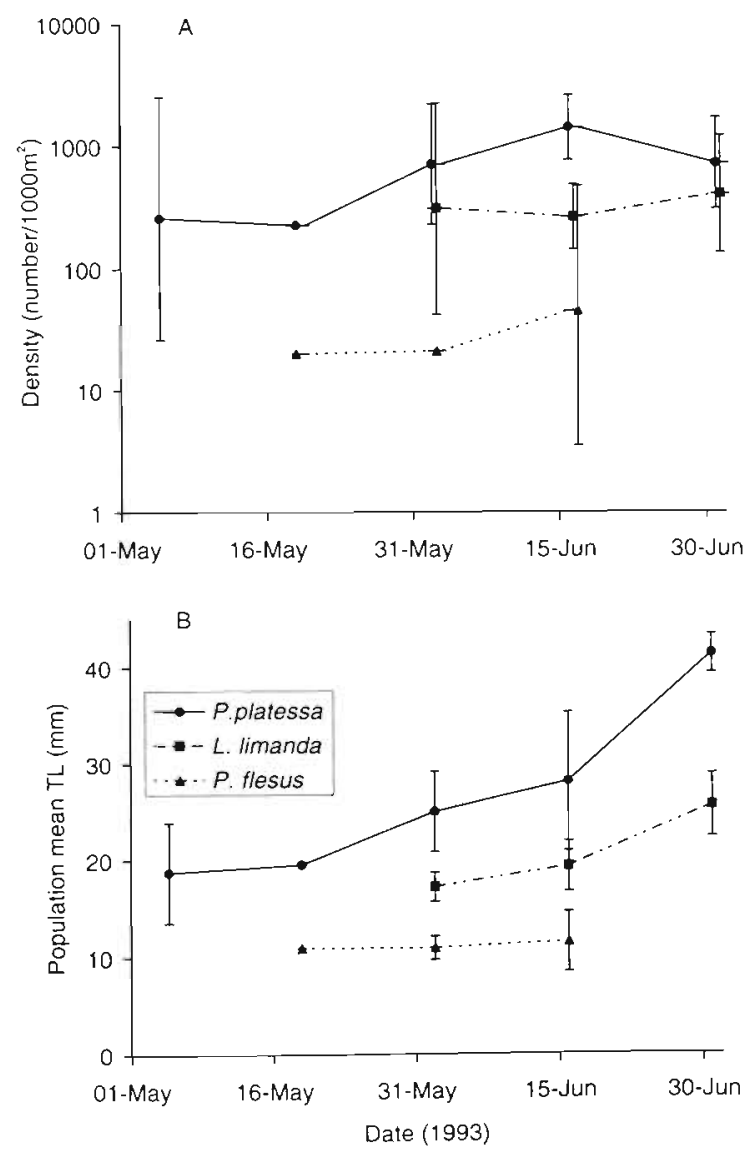

Fig. 2. Flatfish (Pleuronectes platessa, Limanda limanda, Pleuronectes flesus) populations on Tralee Beach, May-July 1993. (A) Population density $195 \%$ confidence limits from $\log (n+1)$ transformation]; (B) population mean lengths $(95 \%$ confidence limits) 
Table 1. Fishes caught from Tralee in 1992 (mid June to end September) and 1993 (early May to early July) examined for evidence of predation on flatfishes (plaice Pleuronectes platessa, dab Limanda limanda, flounder Pleuronectes flesus). Data are \% occurrence

\begin{tabular}{|c|c|c|c|c|c|c|c|c|c|}
\hline \multirow{2}{*}{$\begin{array}{l}\text { Year } \\
\text { Species }\end{array}$} & \multirow{2}{*}{$\begin{array}{l}\text { TL range } \\
(\mathrm{mm})\end{array}$} & \multirow[t]{2}{*}{$n$} & \multirow[t]{2}{*}{ Food } & \multirow{2}{*}{$\begin{array}{l}\text { Crusta- } \\
\text { ceans }\end{array}$} & \multirow{2}{*}{$\begin{array}{l}\text { Poly- } \\
\text { chaetes }\end{array}$} & \multirow{2}{*}{$\begin{array}{l}\text { Round- } \\
\text { fish }\end{array}$} & \multicolumn{3}{|c|}{ Flatfishes } \\
\hline & & & & & & & Plaice & Dab & Flounder \\
\hline \multicolumn{10}{|l|}{1992} \\
\hline Gadus morhua & $28-146$ & 344 & 99.7 & 97.7 & 4.1 & 3.3 & & 5.2 & 0.3 \\
\hline Merlangius merlangus & $37-162$ & 593 & 98.8 & 91.4 & 9.1 & 35.8 & & 0.8 & \\
\hline Trisopterus minutus & $97-128$ & 8 & 100 & 75 & 12.5 & 12.5 & & 25.0 & \\
\hline Trisopterus minutus & $25-85$ & 226 & 100 & 97.3 & 12.4 & 0.4 & & & \\
\hline Pollachius virens & $70-145$ & 27 & 100 & 88.9 & 18.5 & 41.7 & & & \\
\hline Melanogrammus aeglefinus & $122-127$ & 2 & 100 & 100 & 100 & & & & \\
\hline Trisopterus luscus & $50-83$ & 2 & 100 & 100 & & & & & \\
\hline Total & & 1202 & & & & & 0 & 2.1 & 0.1 \\
\hline \multicolumn{10}{|l|}{1993} \\
\hline Eutrigla gurnardus & $69-132$ & 132 & 97.0 & 93.9 & & 15.2 & 8.3 & 6.1 & 3.8 \\
\hline Trisopterus minutus & $95-126$ & 16 & 100 & 100 & & 12.5 & 12.5 & 6.3 & 12.5 \\
\hline Merlangius merlangus & $116-139$ & 4 & 100 & 100 & 25.0 & & 25.0 & & 25.0 \\
\hline Gadus morhua & $29-83$ & 188 & 98.9 & 98.9 & 2.7 & 6.4 & 0.5 & 0.5 & 2.1 \\
\hline Echiicthys vipera & $57-122$ & 29 & 93.1 & 93.1 & 3.4 & 13.8 & 3.4 & & \\
\hline Myoxocephalus scorpius & 143 & 1 & 100 & 100 & & & 100 & & \\
\hline Pleuronectes platessa & $73-203$ & 362 & 100 & 16.0 & 99.4 & 1.9 & & & 0.6 \\
\hline Clupea harengus & $54-135$ & 134 & 97.0 & 97.0 & & 0.7 & & & 1.5 \\
\hline Pomatoschistus spp. & $41-85$ & 143 & 78.3 & 47.6 & 30.8 & 1.4 & & & 0.7 \\
\hline Agonus cataphractus & $46-75$ & 17 & 100 & 100 & & & & & 5.9 \\
\hline Pleuronectes flesus & $71-355$ & 28 & 75.0 & 39.3 & 60.7 & 14.3 & & & \\
\hline Limanda limanda & $65-99$ & 19 & 94.7 & 21.1 & 94.7 & & & & \\
\hline Scophthalmus maximus & 88 & 1 & 100 & 100 & & 100 & & & \\
\hline Merlangius merlangus & $59-88$ & 52 & 94.2 & 92.3 & 5.8 & 3.8 & & & \\
\hline Trisopterus minutus & $26-62$ & 7 & 85.7 & 85.7 & & & & & \\
\hline Pollachius virens & $55-108$ & 2 & 100 & 100 & & 50.0 & & & \\
\hline Salmo trutta & 210 & 1 & 100 & & & 100 & & & \\
\hline Total & & 1136 & & & & & 1.5 & 0.9 & 1.6 \\
\hline
\end{tabular}

\section{Predation on flatifishes}

A total of 112 flatfishes were recovered from the stomachs of fishes. Typically the occurrence of flatfishes was low (Table 1), although one-third of the

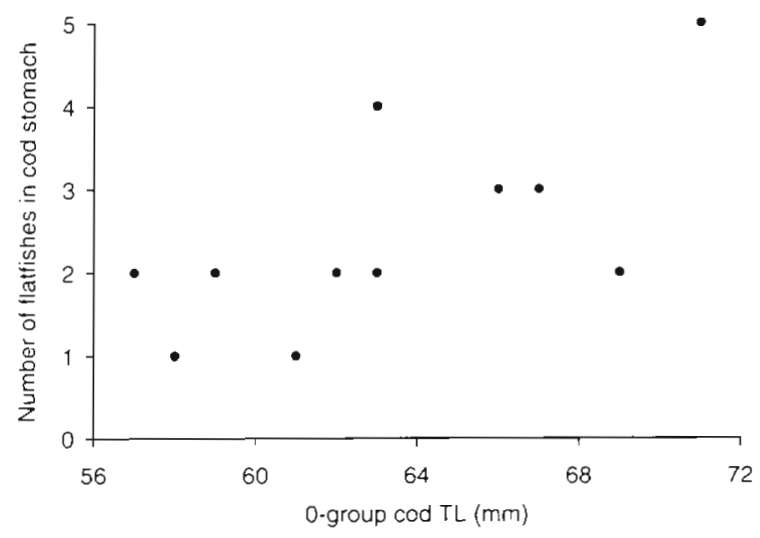

Fig. 3. Number of flatfishes (Limanda limanda, Pleuronectes flesus\} in stomachs of cod Gadus morhua $>56 \mathrm{~mm}$ for the mud June survey 1992 predators that had eaten flatfishes contained more than 1 flatfish, and up to 9 flatfishes were recorded from the stomachs of individual I-group gadoids. Plaice were not recorded from the stomachs of the gadoids sampled in 1992. I-group grey gurnard Eutrigla gurnardus, I-group poor-cod Trisopterus minutus and 0-group cod, and both 0 - and I-group whiting Merlangius merlangus were the most frequent fish predators of flatfishes (Table 1). Flounder were recorded from the stomachs of a greater variety of fish species (hook-nose Agonus cataphractus, I-group plaice, gobies Pomatoschistus spp. and herring Clupea harengus) than plaice and dab.

\section{Predator-prey size relationships}

In the mid June 1992 survey larger cod ate more flatfishes (Fig. $3 ; r_{s}=0.682, n=11, p<0.05$ ), although the relationship was non-significant if the data point for the largest cod was excluded. Larger cod were also found to eat larger flatfishes when the data from all surveys was combined (Fig. $4 \mathrm{~A}_{i} \mathrm{r}_{\mathrm{s}}=0.734, \mathrm{n}=42, \mathrm{p}<$ 

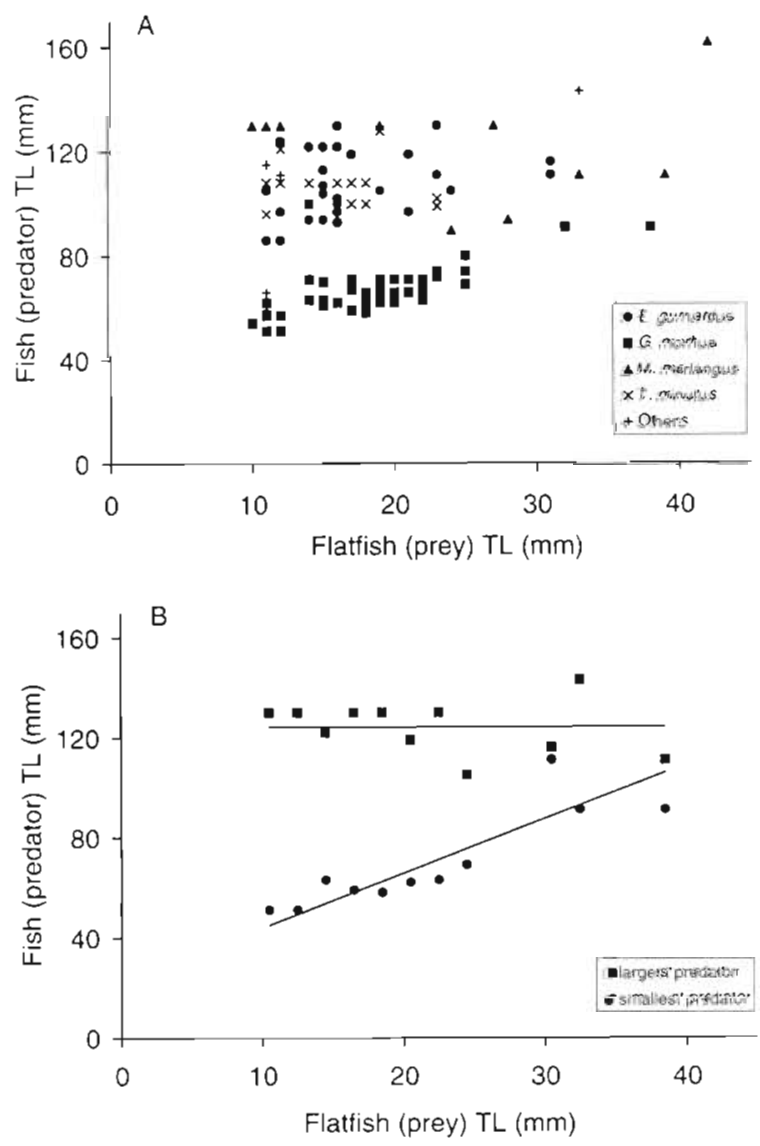

Fig. 4. (A) Observations of fish predator (Eutrigla gurnardus, Gadus morhua, Merlangius merlangus, Trisopterus minutus) size and flatfish prey (Pleuronectes platessa, Limanda limanda and Pleuronectes flesus) size from all surveys in 1992 and 1993. (B) Smallest predator and largest predator recorded of flatfishes (in $2 \mathrm{~mm}$ size classes). Note triangular relationship between size of prey and size range of predators

0.0011 . This may have been, in part, because the sizes of cod and flatfishes are positively correlated due to growth of both species over the period of the surveys (see Fig. 7 later). Combining data therefore ignores the fact that the prey size distribution changes. There was, however, a significant positive correlation between cod size and the size of flatfishes eaten for the survey in mid June $1992\left(r_{s}=0.464, n=27, p<0.05\right.$ ).

Ratios of prey length to predator length from 1992 and 1993 ranged from 0.08 to 0.42 [95\% confidence interval (CI) 0.18 to 0.22 ). Analysis of variance $(F=$ $26.37 ; \mathrm{df}=4,105, \mathrm{p}<0.0001$ ) showed that the ratio for cod was higher than for the other groups shown in Fig. 4 (95\% CI 0.26 to 0.29$)$. There was no relationship between the sizes of predators and flatfishes eaten for the data for all species and surveys combined (Fig. $4 \mathrm{~A}_{;} \mathrm{r}_{\mathrm{s}}=-0.030, \mathrm{n}=110, \mathrm{p}>0.5$ ). However, when the data were pooled into $2 \mathrm{~mm}$ size classes, there was a significant positive correlation between flatfish size and the length of the smallest predator $\left(\mathrm{r}_{\mathrm{s}}=0.888 ; \mathrm{n}=11, \mathrm{p}<0.001\right)$, but no correlation between flatfish size and the length of the largest predator $\left(r_{s}=-0.362 ; n=11, p>0.20\right)$. Smaller flatfishes were therefore eaten by a larger size range of predators than larger individuals (Fig. 4B). The axes of Fig. 4 were intentionally transposed from the usual presentation of such data to show that predator size is as equally dependent on prey size as prey size is dependent upon predator size.

There was a significant negative correlation between the sizes of flatfishes and the number of species of predators feeding on them when the data from the 1993 surveys were pooled into $2 \mathrm{~mm}$ size classes

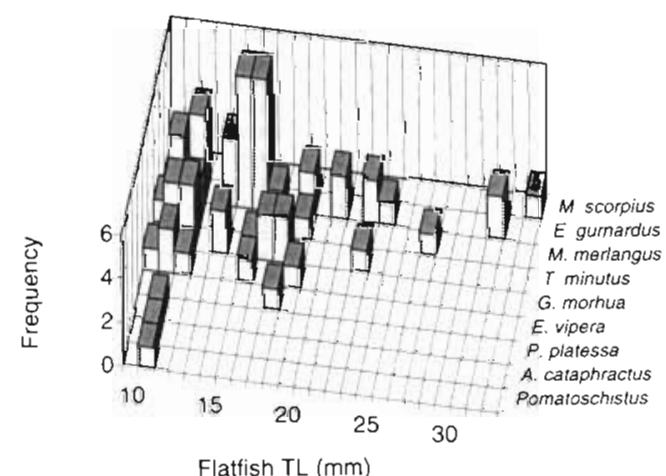

A
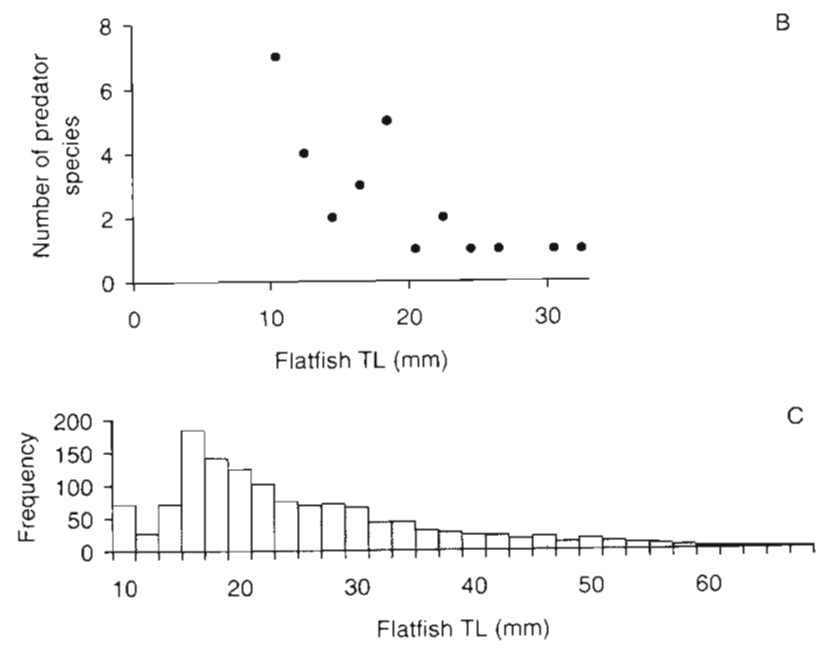

Fig. 5. (A) Frequency (vertical axis) of flatfishes (Pleuronectes platessa, Limanda limanda and Pleuronectes flesus) of different sizes (horizontal axis) found in the stomachs of a variety of fish predators (Myoxocephalus scorpius, Eutrigla gurnardus, Merlangius merlangus, Trisopterus minutus, Gadus morhua, Echithys vipera, P. platessa, Agonus cataphractus, Pomatoschistus spp.) in surveys from early May to early July 1993. (B) Relationship between number of species of predator and size of flatfish, for flatfishes in $2 \mathrm{~mm}$ size classes. (C) Pooled length frequency distribution of flatfish populations sampled from early May to early July 1993 
(Fig. 5B; $r_{s}=0.888 ; n=11, p<0.001$ ). Smaller flatfishes were therefore eaten by a larger taxonomic variety of predators than larger flatfishes. The data for 1992 were not included as only gadoids had been examined. The largest flatfishes found in fish stomachs in 1993 (25 to $33 \mathrm{~mm}$, Fig. 5A) were equally as abundant on the nursery ground as the smallest (10 to $15 \mathrm{~mm}$ ) flatfishes (Fig. 5C; see Fig. 6 for data for separate surveys). The possibility that differential abundance of the different flatfish sizes affected occurrence in the different species (and sizes) of predators can therefore be disregarded.

\section{Prey length distributions}

The sizes of flatfishes eaten were in the smaller size-classes of the flatfishes present on the nursery ground in all 5 surveys of 1993 ( $p<0.05$; Fig. 6). Predation on the plaice population was concentrated on the smaller individuals in mid May $(p<0.005)$ and early June $(p<0.01)$. The length frequency distributions of dabs available on the nursery and recovered from cod stomachs were significantly different in the surveys in mid June and early July 1992 ( $p<0.01$, $p<0.001$ ), predation being skewed towards the smaller size-classes of dab available (Fig. 7A-D).

\section{Predator length distributions}

Only cod $\geq 58 \mathrm{~mm}$ were found to eat dab (Fig. 7E) The length frequency distributions of the cod sam pled, and the cod containing dab were significantly different in mid June and early July $(p<0.001, p<$ $0.01)$. The cod feeding upon dab were in the larger size-classes (Fig. 7E-H). No evidence was found that cod ate flatfishes in the surveys in late August and late September 1992. In mid May 1993, the gurnard that had eaten plaice were in the larger size-classes of the length distribution ( $p<0.01$; Fig. 8).

\section{DISCUSSION}

\section{Problems with predation studies based upon stomach content analysis}

A major problem in investigating predation using stomach contents is the recognition and identification of partially digested prey. Initial recognition of fish remains as flatfish was dependent upon the degree of digestion. The use of Alizarin Red $\mathrm{S}$ to stain calcified tissue proved invaluable because it allowed both the differentiation by meristic features of those remains
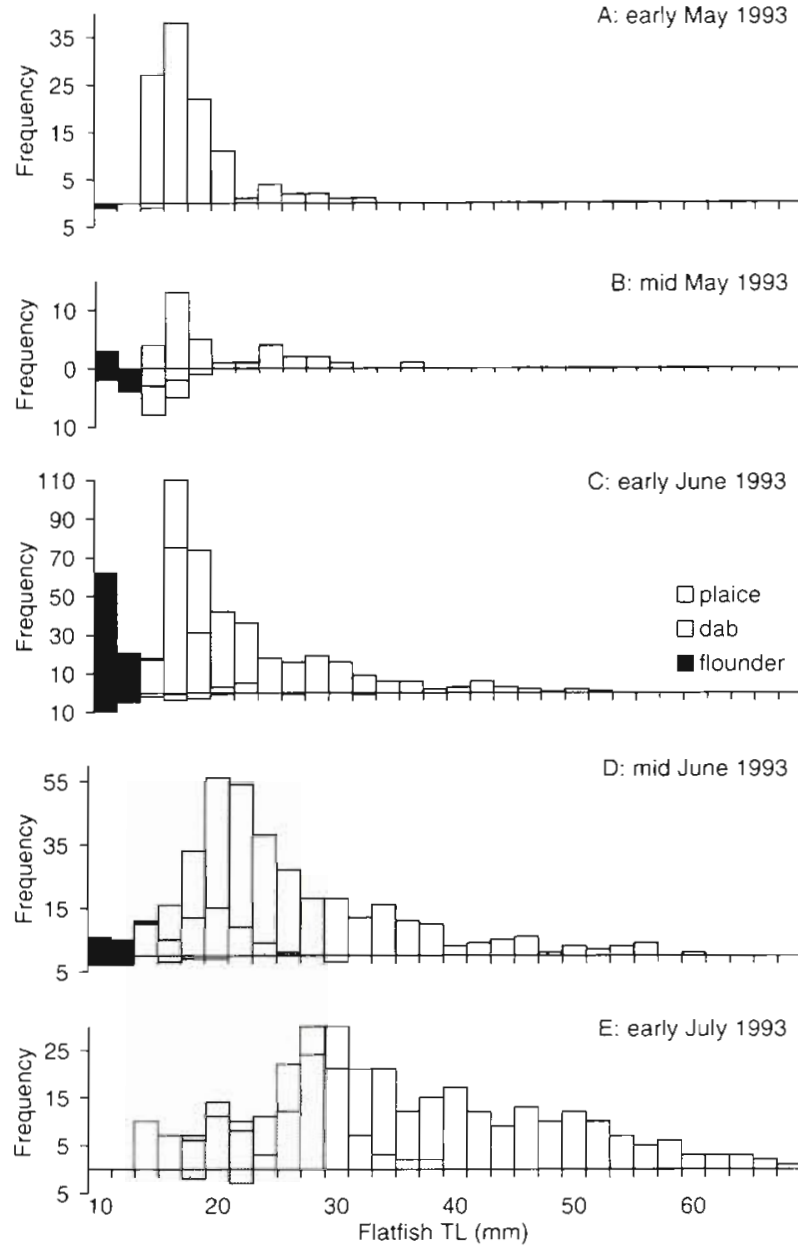

Fig. 6. Length-frequency distributions of flatfishes (Pleuronectes platessa, Limanda limanda. Pleuronectes flesus) recorded in beam trawl catches (corrected for gear efficiency) (above $x$-axis), and length-frequency distributions of flat-

fishes recorded from predator stomachs (below $x$-axis)

previously recognised as flatfishes, and the estimation of original size. The abdominal vertebrae were well suited as a diagnostic feature for these purposes. They are located internally, in the fleshiest part of the fish, and were therefore present after other features had been digested.

A problem of inferring predation upon a population of prey from stomach content analysis is that the population of origin of the prey needs to be verified. We are confident that the flatfishes recovered from predators caught at Tralee originated from the flatfish populations at Tralee. The distance ( 7 to $10 \mathrm{~km}$ ) from the study site to the nearest suitable sandy beaches makes it unlikely that these small predators, even if they were to move from one beach to another, would still have undigested prey remains in their stomachs on arrival. 


\section{Predators of flatfishes}

Edwards \& Steele (1968) and Macer (1967) recorded plaice in the stomachs of $50 \%$ of 0 -group cod and $20 \%$ of I- and IIgroup plaice respectively. Such high incidences of predation were not recorded in the fishes commonly caught from Tralee Beach, despite the fact that the densities of flatfishes were typical for this nursery and similar to those observed in the other study sites (compare Fig. 2A with data in Iles \& Beverton 1991). The predator species that did feed on flatfishes (gadoids and gurnards) fed mostly upon crustaceans (Crangon crangon and amphipods) and other fish species (Table 1). The I-group plaice, dab and flounder, whose main diet was polychaetes, had a very low occurrence of flatfishes or were not recorded as predators. Flatfishes were therefore eaten by those fish species that generally feed on mobile epibenthic crustacea and fishes. I-group grey gurnard, poor-cod and whiting have not previously been recorded as predators of 0-group flatfishes on nursery grounds (compare with Riley \& Corlett 1966, Macer 1967, Edwards \& Steele 1968, Lockwood 1972, Pihl 1982). The fish predators therefore do differ between nurseries, as suggested by Edwards \& Steele (1968)

Flounder larvae still undergoing metamorphosis were found in 2 juvenile herring (TL 105 and $111 \mathrm{~mm}$ ). Juvenile clupeids are often found inshore in shallow water in large numbers (Blaxter \& Hunter 1982, Gibson et al. 1993). They may act as significant predators of flatfish larvae recruiting to nurseries, in addition to invertebrates such as coelenterates that have been recorded feeding on flatfish larvae recruiting to the Wadden Sea (van der Veer 1985).

\section{Prey:predator length ratios}

The range and mean $(0.20)$ of the length ratios of flatfish prey: fish predator were similar to those recorded for fish predators of Japanese flounder Paralichthys olivaceus (Tanaka et al. 1989). Mean length ratios of 0.25 to 0.30 have previously been found for cod and whiting eating fishes (Daan et al. 1990, Hislop et al. 1991, Hop et al. 1994). However, because piscivores
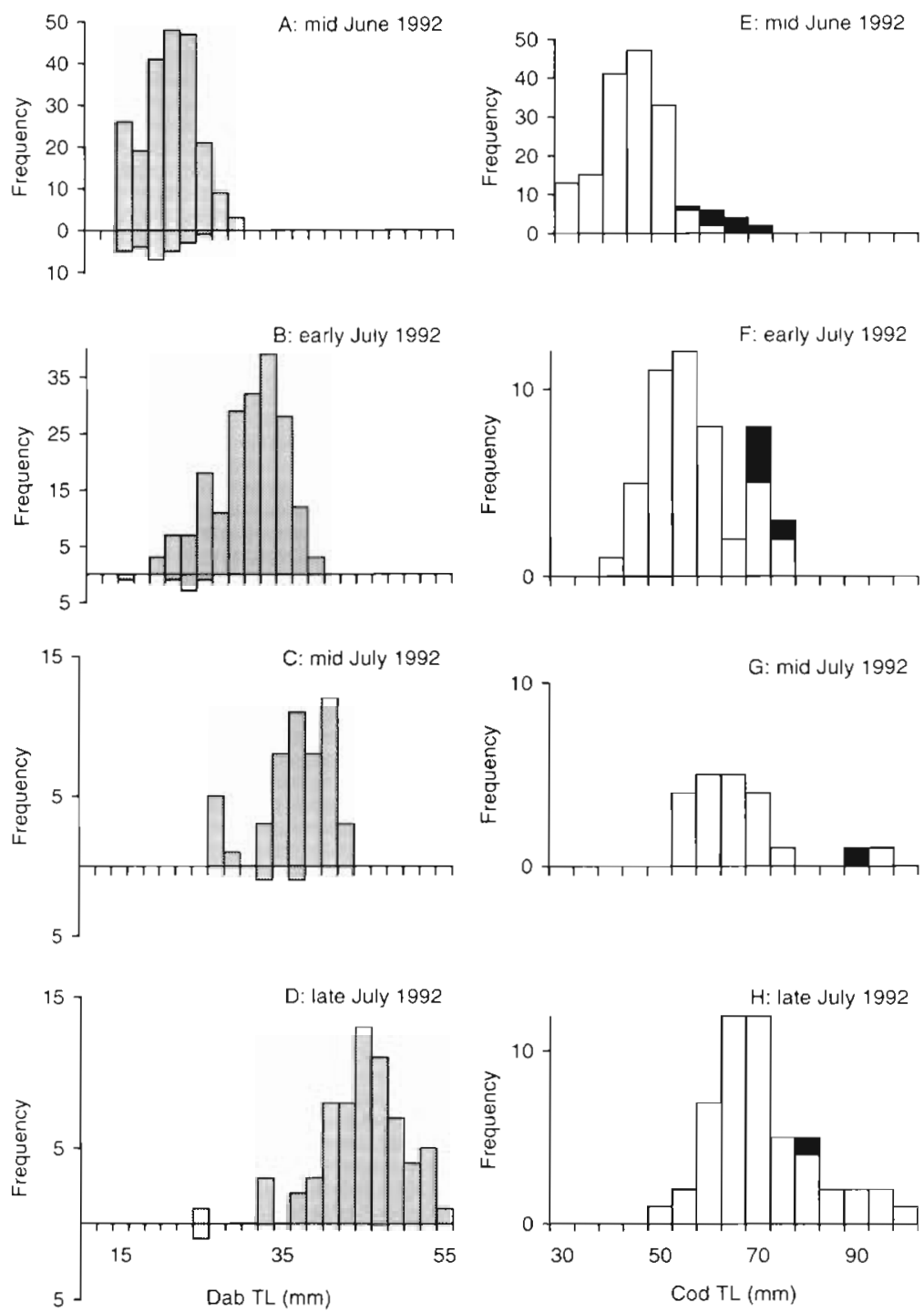

Fig. 7 (A-D) Length-frequency distributions of dab Limanda limanda recorded in beam trawl catches (corrected for gear efficiency) (above $x$-axis), and length-frequency distributions of dab recorded from cod stomachs (below $\mathrm{X}$-axis). (E-H) Length-frequency distribution of 0-group cod Gadus morhua in samples, showing individuals recorded as having eaten dab (black portions of columns)

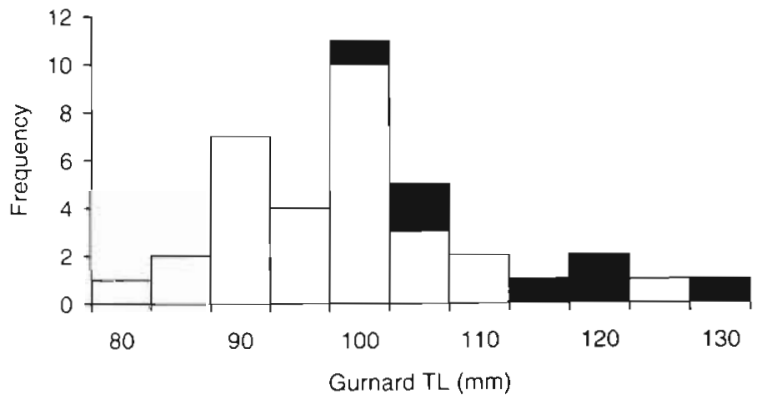

Fig. 8. Length-frequency distribution of I-group grey gurnard Eutrigla gurnardus in beach seine samples in mid May 1993, showing individuals recorded as having eaten plaice Pleuronectes platessa (black portions of columns) 
swallow prey whole, the body depth of fish prey, rather than length, may determine the size of prey consumed (Hambright 1991). The body depth of a flatfish is greater than that of a roundfish of equivalent length. Predator:prey length ratios for flatfishes might therefore be expected to be lower than for other fishes. The predator:prey weight ratio of 0.0064 cited by Dekker (1983), is equivalent to a length ratio of 0.19 (using length-weight relationships given by Coull et al. 1989) for the sizes of cod recorded in this study. The mean ratio for cod recorded in this study $(0.28)$ was higher and indicates that the cod sampled were eating prey large relative to their own body size.

\section{Predator and prey size-distributions}

It was the larger individuals of the I-group gurnard population that ate plaice. The size attained by individuals of the gurnard population would therefore have affected the incidence of predation and hence the number of plaice eaten. Predation rates may therefore be affected by both the abundance and growth of $\geq I$ group predators prior to the restricted period of predation in the summer, that is, during the previous summer, winter and spring.

In mid June 1992, only cod $\geq 58 \mathrm{~mm}$ were found to have eaten dab, despite the presence of large numbers of smaller 0 -group cod. This may be the threshold size at which cod can pursue, capture and handle dab in the field. Such a threshold size may be crucial in determining the effect of 0 -group cod predation on the flatfish populations. In mid June 1992, $58 \mathrm{~mm}$ was in the right-hand tail of the length distribution (Fig. $7 \mathrm{E}$ ), and therefore only the largest cod were eating dabs. If the modal length of the cod population had shifted towards $58 \mathrm{~mm}$, then more cod would have been able to eat dab. Also as larger cod ate more dab, the total number of dab eaten would have been greater. Furthermore, if

Table 2. Mean lengths of cod Gadus morhua and plaice Pleuronectes platessa in June and July 1965 at Firemore Bay (from Edwards 1968. Steele \& Edwards 1970) and at Trajee Beach in 1992 and 1993 , shown as $95 \%$ confidence intervals

\begin{tabular}{|lcccccc|}
\hline Nursery & Year & $\begin{array}{c}\text { Early } \\
\text { June }\end{array}$ & $\begin{array}{c}\text { Mid } \\
\text { June }\end{array}$ & $\begin{array}{c}\text { Early } \\
\text { July }\end{array}$ & $\begin{array}{c}\text { Mid } \\
\text { July }\end{array}$ & $\begin{array}{c}\text { Late } \\
\text { July }\end{array}$ \\
\hline $\begin{array}{l}\text { Cod } \\
\text { Firemore }\end{array}$ & 1965 & & & & & \\
Tralee & 1992 & & $43-46$ & $55-60$ & $61-71$ & $68-74$ \\
& 1993 & $37-44$ & $52-57$ & $57-60$ & & \\
Plaice & & & & & & \\
$\begin{array}{l}\text { Firemore } \\
\text { Tralee }\end{array}$ & 1965 & 20 & 24 & 28 & 37 & 44 \\
& 1992 & & $32-34$ & $52-56$ & $48-53$ & $58-60$ \\
& 1993 & $22-29$ & $23-34$ & $40-43$ & & \\
\hline
\end{tabular}

the dab length distribution had been smaller, then a greater proportion of the population would have been vulnerable to cod because predation was concentrated on the smaller dab. Between mid June and late August 1992, the smaller dabs were apparently outgrowing the larger cod (Fig. 7), although size-selective mortality will have affected the length frequency distribution (Ottera 1992). Outgrowing of predators is not surprising if predator-prey interactions are determined by size ratios. For example to maintain a ratio of 0.25 a prey length increase of $1 \mathrm{~cm}$ would have to be matched by a predator length increase of $4 \mathrm{~cm}$.

In summary, the sizes of both predator and prey affect the extent of predation. In the case of 0 -group cod and 0-group dab, size will be dependent upon the time of settlement, size at settlement and subsequent growth rate. This hypothesis can be extended to include the plaice-cod interaction. In 1992 there was no evidence that cod fed on plaice and in 1993 only one cod was recorded containing a plaice. Plaice settle before dab so the majority of plaice had grown to reach a refuge in size by the time that the 0-group cod recruited to Tralee Beach, mainly in mid to late June, in 1992 and 1993. In June 1965, in Firemore Bay, when Edwards \& Steele (1968) found that many 0-group cod had eaten 0 -plaice, there was an unusually high density of small plaice (compared with the succeeding 3 years) which suffered very high mortality rates (Steele $\&$ Edwards 1970). The mean lengths of the plaice population in Firemore Bay 1965 were smaller than those recorded at Tralee in 1992 and 1993 (Table 2). Also, the mean length of cod, $79 \mathrm{~mm}$, from samples in June and July 1965 from Firemore Bay (Edwards 1968) was larger than all samples taken during the equivalent period at Tralee in 1992 and 1993 (Table 2). The larger cod and smaller plaice in Firemore Bay in 1965 may explain the high occurrence of plaice in cod (Edwards \& Steele 1968) compared to 1992 and 1993 at Tralee.

The significance of 0 -group cod as a predator of 0 group flatfishes may therefore vary in a manner analogous to the 'match-mismatch' hypothesis proposed by Cushing (1972; see Cushing 1990 for recent synthesis) for fish larvae and their planktonic food. 0-group cod may only be an important predator of plaice when there is a large overlap, a 'match', in the size distributions of predator and prey, as at Firemore Bay in 1965. In 1992 at Tralee Beach there was a 'mismatch' in cod and plaice size distributions, and a partial 'match' in the cod and dab size distributions.

\section{Size-selective predation}

Plaice have a size refuge from predation by Crangon crangon at $30 \mathrm{~mm}$, and from Carcinus maenas at $50 \mathrm{~mm}$ 
(van der Veer \& Bergman 1987). No flatfishes $>42 \mathrm{~mm}$ were recovered from the stomachs of the predatory fishes sampled at Tralee. Therefore, once the flatfishes had attained a size of $45 \mathrm{~mm}$ they had apparently outgrown the fish predators present at Tralee, and had a refuge from predation in size. Large fishes, with the potential for preying on flatfishes $>45 \mathrm{~mm}$, e.g. I-group cod, thornback ray Raja clavata, bass Dicentrarchus labrax, sole Solea solea and turbot Scophthalmus maximus (Edwards \& Steele 1968, Lockwood 1972, Pihl 1982, van der Veer et al. 1990) were not caught at Tralee during the study. Their presence at Tralee is deemed unlikely because firstly the beach-seine samples were taken at night when net avoidance will be minimal, and secondly they have not been recorded despite many surveys (pers. obs.; Gibson et al. 1993). Large fishes with the potential to eat juvenile flatfishes are also absent or only present at low density in the Wadden Sea (van der Veer et al. 1990). The absence or low abundance of large predatory fishes will promote the survival of flatfishes, which is partly why nursery grounds are so called (see definition in Gibson 1994).

Predation by fishes on the smaller flatfishes on the nursery ground was demonstrated across species, and within species (plaice and dab). Size-selective mortality occurs when there is differential mortality of different sized individuals in a cohort (Ricker 1969). A process, such as predation, starvation and fishing, causing differential mortality among different sized individuals can then be termed size-selective (e.g. Ricker 1969, Henderson et al. 1988, Litvak \& Leggett 1992). Size-selective mortality may be negative if the smaller individuals suffer higher mortality rates, or positive if the larger individuals are subject to higher mortality rates (Ricker 1969). Differential predation on the smaller flatfishes will have resulted in negative size-selective mortality.

Negative size-selective predation, or the 'bigger is better' hypothesis (Litvak \& Leggett 1992, Leggett \& Deblois 1994) is widely accepted and integral to much recruitment theory (e.g. Shepherd \& Cushing 1980). However, as Chambers \& Leggett (1992) recognised, direct evidence of increased risk of mortality of the smaller members of a cohort is lacking, and has generally been inferred from mortality rates decreasing with size across species, or with development within a single species. Within juvenile flatfishes, density estimates and recapture data have shown that the mortality rate of smaller plaice was greater than that of larger sympatric individuals (Steele \& Edwards 1970, Riley 1973). Yamashita et al. (1994) showed that smaller individuals of hatcheryreared Japanese flounder Paralichthys olivaceus suffered higher mortality rates after release into the natural environment.
The general acceptance of the 'bigger is better' hypothesis for fish larvae and newly settled flatfishes has recently been questioned by Leggett and his coworkers (Litvak \& Leggett 1992, Bertram \& Leggett 1994, Leggett \& Deblois 1994). They recognised that the smaller individuals of a cohort may not always be the most vulnerable to certain predators. Larger individuals may have a higher probability of encounter due to a larger size and greater movements, and may be selectively pursued which could result in positive size selection (Leggett \& Deblois 1994).

However, the sizes of predator and prey are generally positively correlated (e.g. Daan et al. 1990. Hislop et al. 1991). Therefore in relationships involving single species of predator and prey, the size distribution of the predators will determine the size range of prey eaten (see Rice et al. 1993). The size range of prey available will then determine the nature of size selection (see Rice et al. 1993, van der Veer et al. 1994). Cod ate the smaller dab at Tralee presumably because the cod were small relative to the size range of dab available. If such predator-prey relationships are influenced by size ratios, negative size selection might be expected to increase as a population of prey outgrow a group of predators.

Flatfishes are, however, eaten by several species of fishes (see also Riley \& Corlett 1966, Macer 1967, Edwards \& Steele 1968, Lockwood 1972, Pihl 1982), as well as crustaceans (van der Veer \& Bergman 1987, Ansell \& Gibson 1993). Chambers \& Leggett (1992) suggested that smaller flatfishes would be vulnerable to a wider variety of predator species. We have provided evidence in support of the hypothesis that smaller flatfishes were vulnerable to wider variety of fish species. Smaller flatfishes were also vulnerable to a greater size range of fish predators

At Tralee strong negative size-selective predation was observed presumably because of the size structure of the predator fishes present, and the absence of larger fish predators. There is a general trend for numbers of organisms in a system to decrease with increasing body size (e.g. Ursin 1973). Larger fish therefore have larger but less numerous predators (Cushing 1974) and mortality from predation will generally decrease with increasing body size.

The assumption of 'bigger is better' may, however, not be universally applicable and will depend upon the size structure of all potential predators. In some nursery areas large predators of juvenile flatfishes such as birds (cormorant Phalacrocorax carbo and heron Ardea cineraria) may be present (Raffaelli et al, 1990). Raffaelli et al. (1990) suggested that, although herons and cormorants could eat flounder of 50 to $330 \mathrm{~mm}$, they preferentially selected individuals of 100 to $250 \mathrm{~mm}$. An extreme example of positive 
size-selective predation is fishing where, due to the large size of the 'predators', larger fish suffer higher mortality rates due to a higher catchability (Ricker 1969).

\section{Negative size-selective mortality and dampening of year-class strength variation}

Mortality during the juvenile stage of flatfishes is thought to dampen variability in year-class strength generated during the planktonic egg and larval stages (see Bailey 1994). Coherence between modelled growth rate under optimum food conditions and growth rate in the field estimated from changes in population mean length has been used as evidence that growth is not density-dependent in 0-group flatfish populations (Zijlstra \& Witte 1985, Bergman et al. 1988, van der Veer et al. 1990, 1991). However, negative size-selective mortality will exaggerate growth rates estimated from changes in population mean length (Ottera 1992, van der Veer et al. 1994). Indeed Hovenkamp (1991) suggested that size-selective predation may have accounted for the observation that the growth rate of plaice in the field exceeded that predicted by models. Additionally, Edwards et al. (1969) found that the growth rate of plaice in the laboratory underestimated growth in the field. Recently, van der Veer \& Witte (1993) used comparative studies to show that food availability does affect the growth of 0 -group plaice. The former evidence against densitydependent growth of 0-group plaice may therefore be dubious (see van der Veer et al. 1994 for recent review). Density-dependent growth and negative size-selective mortality could combine to result in density-dependent mortality (Shepherd \& Cushing 1980).

The mortality rate of 0 -group plaice on nursery grounds is positively correlated with population density, evidence that mortality is density-dependent (see Beverton \& Iles 1992b). However, population density is also negatively correlated with size because temperature during the planktonic stages affects both the timing of settlement and numbers settling (Zijlstra \& Witte 1985). Higher predation rates on small fish may, therefore, result in a positive correlation between density and mortality without true density-dependent processes occurring (Gibson 1994).

Acknowledgements. This work was undertaken while T.E. was in receipt of a NERC CASE award (University of Liverpool/Dunstaffnage Marine Laboratoryl studentship. Thanks to the numerous people who helped with the fieldwork, and Robin Harvey for demonstration of the Alizarin staining procedure. We also thank the referees, whose constructive critıcism improved the quality of the manuscript.

\section{LITERATURE CITED}

Ansell AD, Gibson RN (1993) The effect of sand and light on predation of juvenile plaice (Pleuronectes platessa) by fishes and crustaceans. J Fish Biol 43:837-845

Bailey KM (1994) Predation on juvenile flatfish and recruitment variability. Neth J Sea Res 32:175-189

Bannister RCA, Harding D, Lockwood SJ (1974) Larval mortality and subsequent year-class strength in plaice (Pleuronectes platessa L.). In: Blaxter JHS (ed) The early life history of fish. Springer Verlag, Berlin, p 21-37

Bergman MJN, van der Veer HW, Zijlstra JJ (1988) Plaice nurseries: effects on recruitment. J Fish Biol. 33 (Suppl A): 201-218

Bertram DF, Leggett WC (1994) Predation risk during the early life history periods of fishes: separating the effects of size and age. Mar Ecol Prog Ser 109:105-114

Beverton RJH, lles TC (1992a) Mortality rates of 0-group plaice (Pleuronectes platessa L.), dab (Limanda limanda L.) and turbot (Scophthalmus maximus L.) in European waters. Il. Comparison of mortality rates and construction of life table for 0-group plaice. Neth J Sea Res 29: $49-59$

Beverton RJH, Iles TC (1992b) Mortality rates of O-group plaice (Pleuronectes platessa L.), dab (Limanda limanda L.) and turbot (Scophthalmus maximus L.) in European waters. IIl Density-dependence of mortality rates of 0 group plaice and some demographic implications. Neth $\mathrm{J}$ Sea Res 29:61-79

Blaxter JHS, Hunter JR (1982) The biology of clupeoid fishes. Adv mar Biol 20:1-223

Burrows MT, Gibson RN, Robb L, Comely CA (1994) Temporal patterns of movement in juvenile flatfishes and their predators: underwater television observations. J exp mar Biol Ecol 177:251-268

Chambers RC, Leggett WC (1992) Possible causes and consequences of variation in age and size at metamorphosis in flatfishes (Pleuronectiformes): an analysis at the individual, population, and species levels. Neth J Sea Res 29: $7-24$

Coull KA, Jermyn AS, Newton AW, Henderson GI, Hall WB (1989) Length/weight relationships for 88 species of fish encountered in the North East Atlantic. DAFS, Fish Res Rep 43

Cushing DH (1972) The production cycle and the numbers of marine fish. Symp zool Soc, Lond 29:213-232

Cushing DH (1974) The possible density-dependence of larval mortality and adult mortality in fishes. In: Blaxter JHS (ed) The early life history of fish. Springer Verlag, Berlin, p 103-111

Cushing DH (1990) Plankton production and year-class strength in fish populations: an update of the match/mismatch hypothesis. Adv mar Biol 26:249-293

Daan N, Bromley JRG, Nielsen NA (1990) Ecology of North Sea fish. Neth J Sea Res 26:343-386

Dekker W (1983) An application of the Andersen consumption model in estimating prey size preference of North Sea cod. Comm Meet Int Counc Explor Sea CM-ICES 1983/ G:63

Edwards RRC (1968) A trophic investigation on a community of young flatfish. $\mathrm{PhD}$ thesis, University of Aberdeen.

Edwards RRC, Finlayson DM, Steele JH (1969) The ecology of 0 -group plaice and common dabs in Loch Ewe. II. Expenmental studies of metabolism. J exp mar Biol Ecol 3:1-17

Edwards RRC. Steele JH (1968) The ecology of 0-group plaice and dabs at Loch Ewe. I. Population and food. J exp mar Biol Ecol 2:215-238 
Ellis $T$ (1994) Production and mortality of early life stages of flatfishes. PhD thesis, University of Liverpool

Gibson RN (1994) Impact of habitat quality and quantity on the recruitment of juvenile flatfishes. Neth J Sea Res 32 $191-206$

Gibson RN, Ansell AD, Robb L (1993) Seasonal and annual variations in abundance and species composition of fish and macrocrustacean communities on a Scottish sandy beach. Mar Ecol Prog Ser 98:89-105

Gibson RN, Yin MC, Robb L (1995) The behavioural basis of predator-prey size relationships between shrimp (Crangon crangon) and juvenile plaice (Pleuronectes platessa). J mar biol Ass UK 57:337-349

Hambright KD (1991) Experimental analysis of prey selection by largemouth bass: role of predator mouth width and prey body depth. Trans Am Fish Soc 120:500-508

Henderson PA, Holmes RHA, Bamber RN (1988) Size-selective overwintering mortality in the sand smelt, Atherina boyeri Risso, and its role in population regulation. J Fish Biol 33:221-233

Hislop JRG, Robb AP, Bell MA, Armstrong DW (1991) The diet and food consumption of whiting (Merlangius merlangus) in the North Sea. ICES J mar Sci 48:139-156

Hop H, Gjosaeter J, Danielssen DS (1994) Dietary composition of sympatric juvenile cod, Gadus morhua L., and juvenile whiting, Merlangius merlangus L., in a fjord of southern Norway. Aquat Fish Mgmt 25(Supp 1):49-64

Hovenkamp F (1991) Immigration of larval plaice (Pleuronectes platessa L.) into the western Wadden Sea: a question of timing. Neth J Sea Res 27:287-296

Iles TC, Beverton RJH (1991) Mortality rates of 0-group plaice (Pleuronectes platessa L.), dab (Limanda limanda L.) and turbot (Scophthalmus maximus L.) in European waters. Neth J Sea Res 27:217-235

Leggett WC, Deblois E (1994) Recruitment in marine fishes: is it regulated by starvation and predation in the egg and Iarval stages? Neth J Sea Res 32:119-134

Litvak MK, Leggett WC (1992) Age and size-selective predation on larval fishes: the bigger-is-better hypothesis revisited. Mar Ecol Prog Ser 81:13-24

Lockwood SJ (1972) An ecological survey of an 0-group plaice (Pleuronectes platessa L.) population, Filey Bay, Yorkshire. PhD thesis, University of East Anglia, Norwich

Lockwood SJ (1980) Density-dependent mortality in 0-group plaice (Pleuronectes platessa L.) populations. J Cons int Explor Mer 39:148-153

Macer CT (1967) The food web in Red Wharf Bay (North Wales) with particular reference to young plaice (Pleuronectes platessa). Helgoländer Wiss Meeresunters 15:560-573

Mahoney R (1968) Laboratory techniques in zoology. Butterworths, London

Norman JR (1934) A systematic monograph of the flatfishes (Heterosomata), Vol 1. Psettodidae, Bothidae, Pleuronectidae. British Museum (Natural History), London

Ottera $\mathrm{H}$ (1992) Bias in calculating growth rates in cod (Gadus morhua L.) due to size selective growth and mortality. J Fish Biol 40:465-467

Pihl L (1982) Food intake of young cod and flounder in a shallow bay on the Swedish west coast. Neth J Sea Res 15 $419-432$

Raffaelli D, Richner H, Summers R, Northcott S (1990) Tidal migrations in the flounder (Platichthys flesus). Mar Behav Physiol 16:249-260

Rice JA, Crowder LB, Rose KA (1993) Interactions between size-structured predator and prey populations: experimental test and model comparison. Trans Am Fish Soc 122:481-491
Ricker WE (1969) Effects of size-selective mortality and sampling bias on estimates of growth, mortality, praduction, and yield. J Fish Res Bd Can 26:479-541

Riley JD (1973) Movements of 0-group plaice, Pleuronectes platessa L. as shown by latex tagging. J Fish Biol 5:323-343

Riley JD, Corlett J (1966) The numbers of 0-group plaice in Port Erin Bay, 1964-66. Rep mar bıol Stn Port Erin 78:51-56

Riley JD, Symonds DJ, Woolner LE (1986) Determination of the distribution of the planktonic and small demersal stages of fish in the coastal waters of England, Wales and adjacent areas between 1970 and 1984. MAFF Fish Res Tech Rep 84

Russell FS (1976) The eggs and planktonic stages of British marine fishes. Academic Press, London

Shepherd JG, Cushing DH (1980) A. mechanism for density-dependent survival of larval fish as the basis of a stock-recruitment relationship. J Cons int Explor Mer 39:160-167

Steele JH, Edwards RRC (1970) The ecology of 0-group plaice and common dabs in Loch Ewe. IV. Dynamics of the plaice and dab populations. J exp mar Biol Ecol 4:174-187

Tanaka M, Goto T, Tomiyama M, Sudo H (1989) Immigration, settlement and mortality of flounder (Paralichthys olivaceus) larvae and juveniles in a nursery ground, Shijiki Bay, Japan. Neth J Sea Res 24:57-67

Ursin E (1973) On the prey size preferences of cod and dab. Meddr Danm Fisk- og Havunders 7:85-98

van der Veer HW (1985) Impact of coelenterate predation on larval plaice Pleuronectes platessa and flounder Platichthys flesus stock in the western Wadden Sea. Mar Ecol Prog Ser 25:229-238

van der Veer HW (1986) Immigration, settlement, and density-dependent mortality of a larval and early postlarval 0group plaice (Pleuronectes platessa) population in the western Wadden Sea. Mar Ecol Prog Ser 29:223-236

van der Veer HW, Berghahn R, Rijnsdorp AD (1994) Impact of juvenile growth on recruitment in flatfish. Neth J Sea Res 32:153-173

van der Veer HW, Bergman MJN (1987) Predation by crustaceans on a newly settled 0-group plaice Pleuronectes platessa population in the western Wadden Sea. Mar Ecol Prog Ser 35:203-215

van der Veer HW, Bergman MJN, Dapper R, Witte JIJ (1991) Population dynamics of an intertidal 0-group flounder Platichthys flesus population in the western Wadden Sea. Mar Ecol Prog Ser 73:141-148

van der Veer HW, Pihl L, Bergman MJN (1990) Recruitment mechanisms in North Sea plaice Pleuronectes platessa. Mar Ecol Prog Ser 64:1-12

van der Veer HW, Witte JIJ (1993) The 'maximum growth/optimal food condition' hypothesis: a test for 0 group plaice Pleuronectes platessa in the Dutch Wadden Sea. Mar Ecol Prog Ser 101:81-90

Watson $T$ (1982) A guide to the identification of pelagic 0 group gadoids. MAFF Fish Res Tech Rep 66

Wheeler A (1969) The fishes of the British Isles and northwest Europe. Macmillan, London

Wheeler A (1992) A list of the common and scientific names of fishes of the British Isles. J Fish Biol 41(Supp A)

Yamashita Y, Nagahora S, Yamada H, Kitagawa D (1994) Effects of release size on survival and growth of Japanese flounder Paralichthys olivaceus in coastal waters off Iwate Prefecture, northeastern Japan. Mar Ecol Prog Ser 105: $269-276$

Zar JH (1984) Biostatistical analysis. Prentice Hall, Englewood Cliffs

Zijlstra JJ, Witte JIJ (1985) On the recruitment of 0-group plaice in the North Sea. Neth J Zool 35:360-376 